\title{
Longitudinal study of subjective well-being of medical students
}

Vladimir Uryvaev

Yaroslavl State Medical University, Yaroslavl, Russia

Goal. Characteristic feature of this study of dynamics of subjective well-being of students was the usage of longitudinal method during their full course of higher education (6 years).

Design and methods of the study. 104 persons participated in the research (therapeutic faculty students of a medical university in central Russia). Every year during 6 years of their education assessment of subjective well-being was performed, using technique of French psychologists Perrudent-Badox, Mendelsohn and Chiche. The method gives general quantitative evaluation of the parameter as well as particular values on its six subscales.

In addition to that multiple-factor personality analysis was performed (using NEO-PR method).

Main results. Among obtained results three are the most important.

First, the aggregate subjective well-being coefficient (which is very low for the firstyear students due to high level of entrance examination distress) grows considerably from the first to the sixth year of education $(p<0.001)$.

Second, subscales of subjective well-being bring distinctive input to the dynamics of the states. Subscales "tension" and "factors, concomitant to the main psychiatric symptomatic" reach maximum at the third year of education. The scales "health-related anxiety" and "satisfaction with day-to-day activity" arrive at the maximum at the second year of education. Other two scales do not demonstrate statistically significant changes.

Third, out of five main NEO-PR scales only one - "neurotism (N)" - demonstrates high correlation (from min $r=0.40(p<0.001)$ up to $\max r=0.71(p<0.001)$ ) for all years of education with sighs of subjective ill-being.

Discussion. Individual characteristics of personalities of medical students can be safely assessed only against the background of "patterns of group-dynamics of personal well-being" of the body of students as a whole.

Consultative work providing support and help in mobilizing inner adaptational resources of students of medical institutions of higher learning is more effective if detailed characteristics of personality are related to the yearly dynamics of subjective well-being in the course of successive years of education.

\section{E-mail: ladoyar@mail.ru}

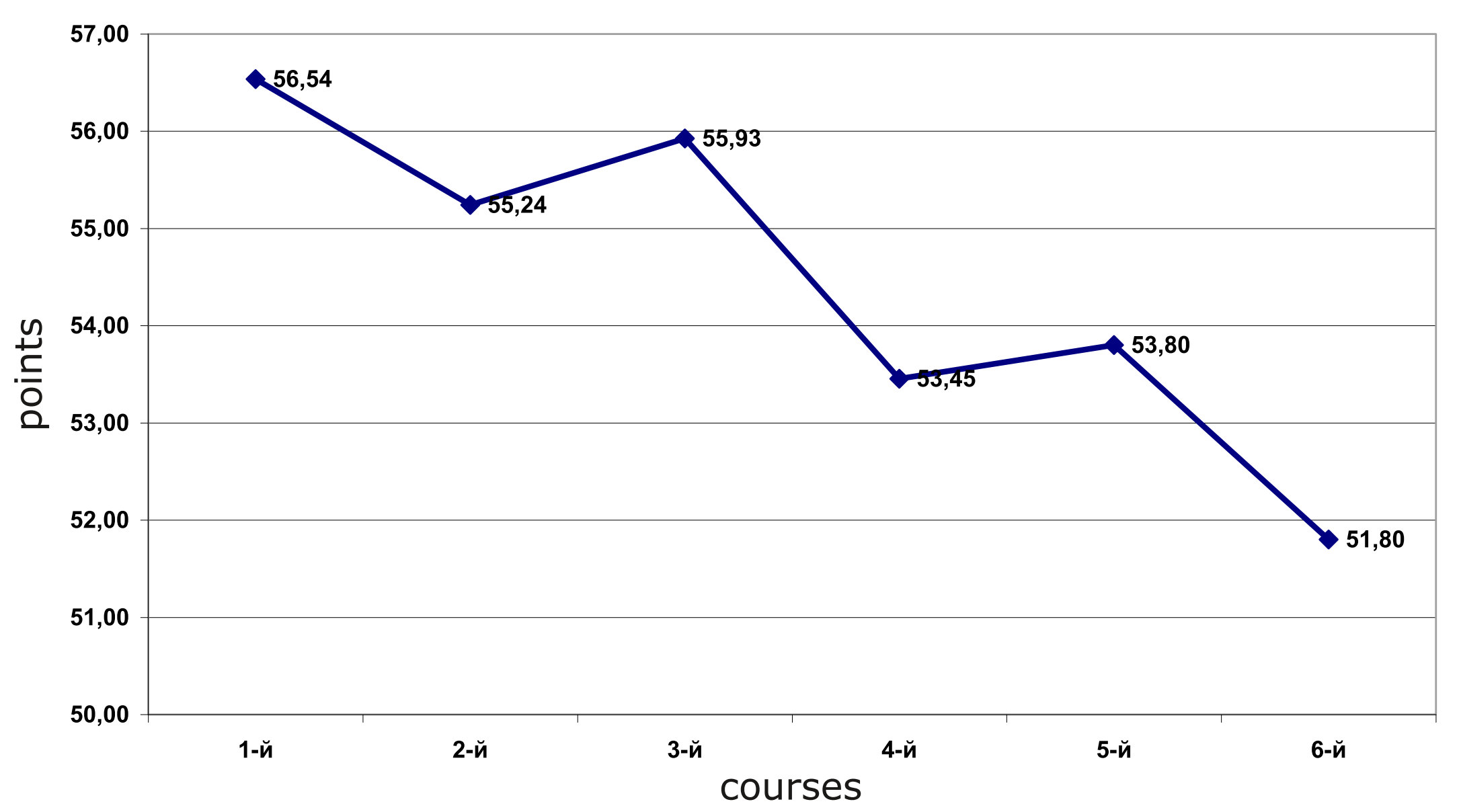

Changes (dependence - inverse - the lower the total indicator, the higher the level of subjective well-being) of the indicators of the total value of the Subjective Well-Being Scale (in raw points) depending on the course of study.

Significant correlations of the total indicator of the Subjective Well-Being Scale and personal qualities (according to the NEO-PR test) enhancing the experience of subjective well-being (according to courses at the medical university, from the same subjects, during 6 years of observation)

\begin{tabular}{|c|c|c|c|c|c|c|c|}
\hline & & $\begin{array}{c}1 \text { course } \\
\text { of learning }\end{array}$ & $\begin{array}{c}2 \text { course } \\
\text { of learning }\end{array}$ & $\begin{array}{c}3 \text { course } \\
\text { of learning }\end{array}$ & \begin{tabular}{|c|}
4 course \\
of learning
\end{tabular} & $\begin{array}{c}5 \text { course } \\
\text { of learning }\end{array}$ & $\begin{array}{c}6 \text { course } \\
\text { of learning }\end{array}$ \\
\hline $\mathbf{N}$ & Neuroticism & & & & & & \\
\hline $\mathbf{E}$ & Extraversion & & & & & & $-0,20^{*}$ \\
\hline E3 & Perseverance & & & $-0,30 * *$ & $-0,23^{*}$ & & $-0,24 * *$ \\
\hline E6 & Positive emotions & & & $-0,24^{*}$ & $-0,31^{\star *}$ & $-0,23^{*}$ & $-0,34^{\star \star \star}$ \\
\hline $\mathbf{O}$ & Openness to experie & & & & & & \\
\hline $\mathbf{A}$ & Cooperation & & & & & & \\
\hline $\mathrm{A} 1$ & The trust & & & & $-0,25^{*}$ & $-0,28 * *$ & $-0,23^{*}$ \\
\hline $\mathrm{C}$ & Conscientiousness & $-0,31^{*}$ & & $-0,24^{*}$ & $-0,34^{\star \star *}$ & & \\
\hline $\mathrm{C} 1$ & Competence & $-0,20^{*}$ & & $-0,37^{* * *}$ & $-0,39^{\star * *}$ & $-0,22^{*}$ & $-0,28^{*}$ \\
\hline $\mathrm{C} 4$ & $\begin{array}{l}\text { Longing for } \\
\text { achievements }\end{array}$ & $-0,25^{*}$ & & $-0,20^{*}$ & $-0,21^{*}$ & & \\
\hline $\mathrm{C} 5$ & Self discipline & $-0,28 * *$ & & $-0,23^{*}$ & $-0,38^{\star * *}$ & & \\
\hline C6 & $\begin{array}{ll}\begin{array}{l}\text { Thinking } \\
\text { deeds }\end{array} & \text { over } \\
\end{array}$ & $-0,20^{*}$ & & $-0,27 * *$ & $-0,26^{* *}$ & & \\
\hline
\end{tabular}

